\title{
Identification of Hsc70 as target for AGE modification in senescent human fibroblasts
}

\author{
Hermann Unterluggauer · Lucia Micutkova • \\ Herbert Lindner · Bettina Sarg • Malin Hernebring • \\ Thomas Nystrom $\cdot$ Pidder Jansen-Dürr
}

Received: 1 July 2008/Accepted: 21 October 2008/Published online: 14 November 2008

(C) The Author(s) 2008. This article is published with open access at Springerlink.com

\begin{abstract}
Cellular senescence is known as a potent mechanism of tumor suppression, and cellular senescence in vitro also reflects at least some features of aging in vivo. The Free Radical Theory of aging suggests that reactive oxygen species are important causative agents of aging and cellular senescence. Besides damage of nucleic acids and lipids, also oxidative modifications of proteins have been described as potential causative events in the senescence response. However, the identity of protein targets for post-translational modifications in senescent cells has remained unclear. In the present communication, we analyzed the occurrence of oxidative posttranslational modifications in senescent human endothelial cells and dermal fibroblasts. We found a significant increase in the level of protein carbonyls and AGE modification with senescence in
\end{abstract}

H. Unterluggauer · L. Micutkova · P. Jansen-Dürr ( $\square)$ Institute for Biomedical Aging Research, Austrian Academy of Sciences, Rennweg 10, 6020 Innsbruck, Austria

e-mail: p.jansen-duerr@oeaw.ac.at

H. Lindner · B. Sarg

Innsbruck Biocenter, Division of Clinical Biochemistry, Medical University of Innsbruck, Fritz-Preglstrasse 3, 6020 Innsbruck, Austria

\section{Hernebring · T. Nystrom}

Department of Cell and Molecular Biology, University of Gothenburg, Göteborg University, Medicinaregatan 9C,

P.O. Box 462, 41390 Göteborg, Sweden both cell types. Using 2D-Gel electrophoresis and Western Blot we found that heat shock cognate protein 70 is a bona fide target for AGE modification in human fibroblasts.

Keywords Fibroblasts - Endothelial cells ·

Senescence $\cdot$ Protein carbonyls .

Advanced glycation end products .

Hsc 70
Abbreviations
HDF Human diploid fibroblasts
HUVEC Human umbilical vein endothelial cells
DTT Dithiothreitol
HSC70 Heat shock cognate protein 70
AGE Advanced glycation end products

\section{Introduction}

The free radical theory of aging (Harman 1956) implicates molecular damage caused by reactive oxygen species (ROS) as a major cause of aging processes in most if not all species. Besides DNA damage, proteins are recognized as major targets of oxidative modification. Hence, the accumulation of oxidatively modified proteins has been reported in many experimental aging models, as measured by the level of intracellular protein carbonyls or dityrosine, or by the accumulation of protein-containing pigments such as lipofuscin and ceroid bodies (Grune 
et al. 2001; reviewed by Levine and Stadtman 2001). Whereas protein carbonyls are irreversible within living cells, other oxidative damage to proteins can be repaired in some cases, e.g., by methionine sulfoxide reductases (Msrs) (Petropoulos and Friguet 2005); alternatively, damaged proteins can be removed by proteasomes and lysosomes. However, both proteasome activity (Bulteau et al. 2000) and Msr expression (Petropoulos and Friguet 2005) were shown to decline with aging, indicating that the accumulation of oxidized proteins may be involved in many aging processes (for review, see Widmer et al. 2006). In addition, the formation of protein adducts with advanced glycation end products (AGE) and advanced lipid peroxidation end products, such as 4hydroxy-trans-2-nonenal (HNE), is found in many aged tissues. These modifications are irreversible in most cases and are thought to contribute to a variety of age-associated diseases (reviewed by Reddy and Beyaz 2006).

The role of ROS as mediators of senescence and determinants of lifespan has been addressed by genetic studies in model organisms (for review, see Sohal et al. 2002). Thus, reducing the level of antioxidant enzymes, such as superoxide dismutase (SOD) leads to a consistent reduction of the lifespan in many species, including mice (Kokoszka et al. 2001). Accordingly, extending the antioxidative capacity, for example by overexpression of SOD/ catalase (Orr and Sohal 1994) was shown to extend lifespan in an otherwise short-lived strain of the fruitfly D. Melanogaster, whereas ectopic overproduction of mitochondrial catalase can prolong the life span of mice (Schriner et al. 2005). However, there are also examples where overexpression of antioxidant proteins did not extend the lifespan; thus, a large cohort study demonstrated that overexpression of CuZnSOD does not increase lifespan of the mouse (Huang et al. 2000); similarly, catalase transgenic mice are not long lived but rather display enhanced sensitivity to oxidative stress (Chen et al. 2004). Whereas these data support the concept that ROSinduced damage contributes to aging processes, at least in some specific genetic backgrounds, the role of the individual antioxidant enzymes in this process remains to be determined. Concerning human aging, the situation is less clear, in particular due to the absence of suitable experimental model systems. Many questions about molecular mechanisms of human aging have been addressed using in vitro senescence models derived from normal human cells. The proliferation potential of human primary cells in culture is limited, and extended passaging of such cells leads to a state of terminal growth arrest, referred to as replicative senescence (reviewed by Hayflick 1997).

While the erosion of telomeres, due to insufficient telomerase activity (reviewed by Shay and Wright 2001) has been recognized as a primary cause of cellular senescence, a variety of other events have been identified that trigger (premature) senescence, including oxidative stress (von Zglinicki et al. 1995), adverse cell culture conditions (Ramirez et al. 2001), the expression of oncogenes, and a variety of additional stimuli (reviewed by Serrano and Blasco 2001; Toussaint et al. 2002). Whereas impairment of tumor growth by cellular senescence is now known as a potent tumor suppressor mechanism (reviewed by Braig and Schmitt 2006), the role of cellular senescence in aging is still controversial. Nevertheless, cellular senescence has been widely used as a model system to study aging of various human tissues, and limited experimental evidence suggests that the occurrence of cells with a senescence-like phenotype is not restricted to tissue culture experiments, but such cells are also observed in aged tissue in vivo, such as the human skin (Dimri et al. 1995; Ressler et al. 2006) or the human vascular system (Vasile et al. 2001). The premature appearance of senescent cells in the vascular endothelium has been associated with the onset of age-associated cardiovascular diseases, such as arteriosclerosis (Minamino et al. 2002).

An increase in oxidative stress and ROS production has been reported to occur with cellular senescence in several human cell types, including both human fibroblasts (Goldstein and Korczack 1981; Martinez et al. 1987) and endothelial cells (Ungvari et al. 2008; Unterluggauer et al. 2003, 2007). It was shown that the proportion of damaged proteins increases with replicative senescence in several cell types, including human diploid fibroblasts (HDF) (Ahmed et al. 2007; Grune et al. 2001; Petropoulos et al. 2000) and human umbilical vein endothelial cells (HUVEC) (Unterluggauer et al. 2007). However, the cellular proteins that are targeted by oxidative modifications have not been identified in most cases. 


\section{Materials and methods}

Cell culture

Human diploid fibroblasts were (HDF) isolated from human foreskin as described (Wagner et al. 2001) and cultured in Dulbecco's modified Eagle's medium (Gibco Life Technologies, Vienna, Austria), supplemented with penicillin/streptomycin solution (Gibco Life Technologies) and 10\% (v/v) fetal calf serum (Gibco Life Technologies). The culture medium contained substrates for cellular energy metabolism, such as glucose $(5 \mathrm{mM})$, pyruvate $(1 \mathrm{mM})$ and Lglutamine $(4 \mathrm{mM})$. The cells were subcultured in an atmosphere of $5 \% \mathrm{CO}_{2}$ in air at $37^{\circ} \mathrm{C}$ by passaging them at a ratio of 1:5 at regular intervals. For passages in aged cells, the splitting ratio was progressively decreased to 1:3 and 1:2. PDL (population doubling) was estimated using the equation $\mathrm{PDL}=$ $(\log F-\log I) / 0.301$, where $F$ is the number of cells at the end of one passage and $I$ the number of cells that were seeded at the beginning of one passage. After approx. 55 PDL, the cells reached growth arrest. The senescent status was verified by in situ staining for senescence-associated $\beta$-galactosidase (SA- $\beta$-gal)as described (Dimri et al. 1995); $>99 \%$ of the cells stained SA-B-gal positive. In addition, the senescent status was verified by indirect immunofluorescence analysis of cyclin A, which documents G1 cell cycle arrest, as described (Wagner et al. 2001). No cyclin A positive cells were detected in senescent HDF cultures.

Human umbilical vein endothelial cells (HUVEC) were isolated from human umbilical veins as described (Jaffe et al. 1973) and cultured in Endothelial Cell Basal Medium (Cambrex BioScience, Verviers) supplemented with EGM Singlequots (Cambrex BioScience, Verviers), containing $0.1 \%$ hEGF, $0.1 \%$ hydrocortisone, $0.1 \%$ GA-1000, $0.4 \% \mathrm{BBE}$ and $2 \%$ FBS. The cells were subcultured by trypsinization with trypsinEDTA (Gibco Life Technologies, Vienna, Austria), seeded on cell culture dishes coated with $0.2 \%$ gelatine and grown in an atmosphere of $5 \% \mathrm{CO}_{2}$ at $37^{\circ} \mathrm{C}$. Cells were passaged at a ratio of 1:5 in regular intervals. At later passages, the splitting ratio was reduced to $1: 3$ and $1: 2$, respectively. Cells were passaged such that the monolayers never exceeded 70-80\% confluency. PDL were estimated using the following equation: $n=(\log 10 F-\log 10 I) / 0.301$ (where $n$ is the population doublings, $F$ the number of cells at the end of one passage, and $I$ is the number of cells that were seeded at the beginning of one passage). After roughly 65 population doublings, the cells reached growth arrest, corresponding to $90-95 \%$ SA- $\beta$-gal positive cells. In agreement with previous studies (Wagner et al. 2001), the amount of cyclin A-positive cells decreased from 25 to $30 \%$ in young cultures to $1-2 \%$ in senescent HUVEC cultures.

Analysis of oxidatively modified proteins

To prepare cell extracts for the detection of oxidized proteins, cells were washed two times in ice-cold PBS, harvested in a lysis buffer containing $50 \mathrm{mM}$ sodium phosphate buffer ( $\mathrm{pH} 7.8$ ), $150 \mathrm{mM} \mathrm{NaCl}$, $1 \%$ deoxycholate (Na-based), $0.1 \%$ SDS, $2 \mathrm{mM}$ EDTA, $50 \mathrm{mM}$ DTT, and $1 \mathrm{mM}$ Pefabloc (Roche). Cell lysates were centrifuged at $14,000 \mathrm{~g}$ for $15 \mathrm{~min}$ at $4^{\circ} \mathrm{C}$, protein concentration determined by a Detergent Compatible-assay (DC-assay; Biorad, Germany) and the supernatants separated on $10 \%$ SDS/polyacrylamide gels (Biorad). After electrophoresis, proteins were transferred to PVDF membranes by wet electroblotting and blocked in 5\% PBSTM (5\% milk, $0.1 \%$ tween 20). Immunoreactive proteins were detected using an enhanced chemiluminescence system (Amersham Life Science, Braunschweig, Germany). Immunodetection was performed using a mouse monoclonal anti-AGE antibody (6D12; TransGenic Inc., Japan) and mouse monoclonal anti-alpha tubulin (Sigma, Vienna, Austria) following detection with horseradish peroxidase-conjugated anti-mouse secondary antibody (DAKO, Glostrup, Denmark). For determination of carbonyl levels, proteins $(5 \mu \mathrm{g})$ were derivatized with DNPH according to the manufacturer's protocol (Chemicon, Temecula, CA, USA). Derivatized samples were separated on $10 \%$ SDS/polyacrylamide gels and immunoblotting performed as described above. As a positive control for oxidatively modified proteins, cells were incubated with $750 \mu \mathrm{M} \mathrm{H}_{2} \mathrm{O}_{2}$ for $1.5 \mathrm{~h}$.

\section{D-gelelectrophoresis and immunoblotting}

Cells were washed two times in ice-cold PBS, lysed for $30 \mathrm{~min}$ on ice in a buffer (RIPA-Buffer) containing $50 \mathrm{mM}$ sodium phosphate buffer ( $\mathrm{pH} 7.8$ ), $150 \mathrm{mM}$ $\mathrm{NaCl}, 1 \%$ Deoxycholate (Na-based), $0.1 \%$ SDS, $2 \mathrm{mM}$ EDTA, $50 \mathrm{mM}$ DTT and $1 \mathrm{mM}$ Pefabloc 
(Roche). or (stringent SDS-Buffer) $50 \mathrm{mM}$ Tris- $\mathrm{HCl}$ pH 8, $150 \mathrm{mM} \mathrm{NaCl}, 1 \% \mathrm{NP}-40,0.5 \%$ DOC, $0.1 \%$ SDS and 1 complete, Mini, EDTA-free Protease Inhibitor Cocktail Tablet (Roche, Austria). The lysates were centrifuged at $20,000 \mathrm{~g}$ for $10 \mathrm{~min}$ at $4^{\circ} \mathrm{C}$, and the supernatants were clarified by centrifugation. Samples for two-dimensional gel electrophoresis (2D-GE) were chloroform/MeOH precipitated (Wessel and Flugge 1984). Briefly, $150 \mu \mathrm{g}$ of protein were precipitated and redisolved in 2D-GE-Buffer (8 M urea, $4 \%$ CHAPS, 65 mM DTT, 0.7\% IPG buffer, pH 3-11). Samples were aliquoted and stored at $-70^{\circ} \mathrm{C}$ before use. Samples (60 or $120 \mu \mathrm{g}$ of protein) were subjected to isoelectric focusing (IEF) using IPGDry strips with immobilized non-linear $\mathrm{pH}$ gradient, $\mathrm{pH}$ range 3-11, $18 \mathrm{~cm}$, (GE Healthcare). Samples were loaded by the in-gel rehydration technique, with active loading during $12 \mathrm{~h}$. IEF was performed in an IPGphor (GE Healthcare) according to the following protocol: rehydration $12 \mathrm{~h}$ at $30 \mathrm{~V} ; 0.5 \mathrm{~h}, 200 \mathrm{~V} ; 0.5 \mathrm{~h}$, $500 \mathrm{~V} ; 0.5 \mathrm{~h}, 1,000 \mathrm{~V}, 2 \mathrm{~h}$ gradient to $8,000 \mathrm{~V}, 7 \mathrm{~h}$ at $8,000 \mathrm{~V}$ or to $72,000 \mathrm{~V}$. After IEF, strips were equilibrated in $50 \mathrm{mM}$ Tris- $\mathrm{HCl}, \mathrm{pH} 8.8,6 \mathrm{M}$ urea, $2 \%$ SDS, $30 \%$ glycerol with $1 \%$ DTT for $10 \mathrm{~min}$, and then for $10 \mathrm{~min}$ in the same buffer without DTT but with $4 \%$ iodoacetamide. Equilibrated strips were placed on top of $10 \%$ polyacrylamide gels and fixed with $0.5 \%$ agarose in a concentrating buffer $(62.5 \mathrm{mM}$ Tris-HCl, pH 6.8, 0.1\% SDS). The SDS-PAGE was performed in a Biorad Protean XL.device following the manufacturer's recommendations (constant power $15 \mathrm{~W}$, run for $15 \mathrm{~h}$ over night). After electrophoresis, the proteins were transferred to PVDF membranes by wet electroblotting in a buffer containing $25 \mathrm{mM}$ Tris-HCl, $190 \mathrm{mM}$ glycine, $0.5 \%$ SDS, $10 \%$ methanol. Immunoreactive proteins were detected using an enhanced chemiluminescence system (Amersham Life Science, Braunschweig, Germany). The following antibodies were used for Western blot analysis: monoclonal antibodies against $\beta$-Actin (Sigma, Vienna), Hsc70 antibodies (Stressgen, SPA-815) and monoclonal anti-AGE (Transgenic Inc., Japan, clone 6D12); secondary antibody anti-mouse IgG HRPconjugated were obtained from DAKO.

Mass-spectrometric analysis

The silver gel and AGE Western blot were overlaid to identify spots on the silver gel that correspond to
AGE-modified proteins. Positioning of the gel relative to the Western Blot was controlled by standard methodology, using in particular the molecular weight markers loaded on both margins of the second dimension gel. As additional reference point, a single spot is revealed with actin antibodies, which is easily visible in silver gels as well. Seven discrete spots obtained by gel electrophoresis were cut out, in-gel digested with trypsin and analyzed by nanospraytandem mass spectrometry. Protein digests were analyzed using a preconcentrator in combination with a self-constructed fritless nano-spray column $(100 \mu \mathrm{m}$ i.d. $\times 365 \mu \mathrm{m}$ o.d; packed $10 \mathrm{~cm}$ with $5 \mu \mathrm{m} \mathrm{C}_{18}$ material), analyzed by mass spectrometry (LTQ ion trap instrument, Thermo Finnigan). The nano-HPLC separation for MS-analysis was done with an UltiMate 3000 pump (Dionex; Sunnyvale, CA) with a flow rate of $300 \mathrm{nl} / \mathrm{min}$ using gradient elution (solvent A: $0.1 \%$ formic acid in water; solvent B: $85 \%$ acetonitrile/ $0.1 \%$ formic acid) starting at $4 \%$ B. The concentration of solvent B was maintained at $4 \%$ during $2 \mathrm{~min}$, increased linearly to $50 \%$ during $50 \mathrm{~min}$ and from 50 to $100 \%$ during $10 \mathrm{~min}$. Protein identification was performed using the SEQUEST algorithm in the Bioworks 3.3 software package (Thermo-Electron Corp.) and a human database. The identified peptides were further evaluated using charge state versus cross-correlation number (Xcorr). The criteria for positive identification of peptides were Xcorr $>1.5$ for singly charged ions, Xcorr $>2.0$ for doubly charge ions, and Xcorr $>2.5$ for triply charged ions. Only best matches were considered.

Immunoprecipitation

After $2 \times$ wash in ice-cold PBS extracts from senescent fibroblasts were prepared in lysis buffer $(50 \mathrm{mM}$ $\mathrm{Na}_{2} \mathrm{HPO}_{4} / \mathrm{NaH}_{2} \mathrm{PO}_{4}$-Buffer pH 7.2, $150 \mathrm{mM} \mathrm{NaCl}$, $1 \%$ Triton $\mathrm{X}-100,2$ mM EDTA, $0,5 \%$ Na-DOC, $0.1 \%$ SDS, $0.2 \mathrm{mM}$ PMSF, $1 \mathrm{mM} \mathrm{NaF}, 0.1 \mathrm{mM} \mathrm{Na}_{3} \mathrm{VO}_{4}$ and $10 \mu \mathrm{g} / \mathrm{ml}$ Aprotinin). After storage on ice for $30 \mathrm{~min}$ the lysates were centrifuged at $14,000 \mathrm{~g}$ for $15 \mathrm{~min}$ at $4^{\circ} \mathrm{C}$ to pellet debris. Supernatants were precleared for $1 \mathrm{~h}$ with $100 \mu \mathrm{l}$ of Protein A/G PLUSAgarose beads (Santa Cruz) and then used for subsequent immunoprecipitations overnight at $4{ }^{\circ} \mathrm{C}$. To monitor the oxidative modification of $\mathrm{Hsc} 70$, $250 \mu \mathrm{g}$ of protein extract was used in a total volume of $500 \mu$ l together with $100 \mu$ Protein A/G PLUS beads 
Fig. 1 The formation of protein carbonyls is increased in senescent human cells. a Young human diploid fibroblasts were either untreated or treated for $1.5 \mathrm{~h}$ with $750 \mu \mathrm{M} \mathrm{H}_{2} \mathrm{O}_{2}$, as indicated. Cells were extracted in the absence or presence of $50 \mathrm{mM}$ DTT as indicated and cellular proteins derivatized with DNPH. Subsequently, cell extracts were run on SDS-PAGE and probed with specific antibodies for the DNP moiety (Oxyblot $\left.^{\mathrm{TM}} \mathrm{Kit}\right)$. Coomassie-stained PVDF membranes are shown in the lower panel as loading control. In the control (co), derivatization was carried out with buffer alone, as an additional control to show that there is no background staining. Morphological changes obtained by incubation with $\mathrm{H}_{2} \mathrm{O}_{2}$ are documented in the right panel. $\mathbf{b}$ Analysis of protein carbonyls in young versus senescent fibroblasts. Young and senescent human diploid fibroblasts were extracted in the presence or absence of $50 \mathrm{mM}$ DTT, as indicated. Proteins were DNPH derivatized and run on a $10 \%$ SDS gel followed by

and $10 \mu \mathrm{g}$ of rat anti Hsc70 antibody (Stressgen, SPA815). Beads were washed four times in lysis buffer, resuspended in 1 volume of $2 \times$ Laemmli buffer, boiled at $95^{\circ} \mathrm{C}$ for $5 \mathrm{~min}$, centrifuged for $3 \mathrm{~min}$ at $14,000 \mathrm{rpm}$ and loaded onto SDS-gel. Precipitated proteins were visualized by Western blot.

\section{Results and discussion}

Increased formation of protein carbonyls in senescent cells

It is known that reactive oxygen species such as superoxide can induce oxidative damage to cellular proteins, among which the formation of protein carbonyls is one prominent form of oxidative modification (Stadtman and Levine 2000). To analyze this process we adopted a protocol for the detection of carbonylated proteins in cellular extracts. Attempts to detect protein carbonyls by commercial kits (e.g., Oxyblot $^{\mathrm{TM}}$ kits) yielded variable results, which were found to depend on the quality of commercially available reagents as well as on experimental conditions (our unpublished results). To validate the experimental protocol used in this communication, young proliferating human diploid fibroblasts (HDF) were either treated with $\mathrm{H}_{2} \mathrm{O}_{2}$ for $1.5 \mathrm{~h}$ or left untreated. Subsequently, proteins were extracted and prepared for Oxyblot ${ }^{\mathrm{TM}}$ analysis. To assess the influence of potential protein oxidation occurring during as well as after lysis of the cells, protein extraction was performed in the presence of $50 \mathrm{mM}$ immunodetection with specific antibodies for the DNP moiety (Oxyblot $\left.{ }^{\mathrm{TM}} \mathrm{Kit}\right)$. In the negative controls, either no cell extract was used for derivatization or cell extract was loaded, but derivatization omitted, as indicated. As positive control, a prestained marker for protein carbonyls was loaded. Immunoblotting against alpha tubulin served as a loading control. c Analysis of protein carbonyls in young versus senescent HUVEC. Young and senescent HUVEC were grown with or without $\mathrm{H}_{2} \mathrm{O}_{2}$ for $1.5 \mathrm{~h}$. Cells were then extracted in the presence or absence of $50 \mathrm{mM}$ DTT, as indicated. Cellular proteins were derivatized by DNPH and subsequently separated by $10 \%$ polyacrylamide gel electrophoresis. Gels were blotted and probed with specific antibodies for the DNP moiety (Oxyblot ${ }^{\mathrm{TM}}$ Kit). In the control, no protein extract has been derivatized before loading. Western blotting to alpha tubulin served as a loading control. $\mathrm{H}_{2} \mathrm{O}_{2}$-induced changes of the cellular phenotype are documented in the right panel

DTT, whereas control samples were processed in lysis buffer without additional DTT. Subsequently, proteins were derivatized by DNPH, separated by SDS-PAGE and carbonylated proteins were detected by immunoblotting with an anti-DNP antibody. The signal obtained in $\mathrm{H}_{2} \mathrm{O}_{2}$ treated cells was significantly higher than in untreated cells, suggesting that the protocol is suitable for the detection of carbonylated proteins. Surprisingly, we found that the addition of DTT to the standard lysis buffer suppressed a large proportion of the signal (Fig. 1a). This finding suggests that the signals obtained with standard Oxyblot $^{\mathrm{TM}}$ from young fibroblasts are derived in part from carbonylated proteins that exist within the cells prior to lysis, but that a large proportion of protein carbonyls were artificially generated during and after lysis when DTT was omitted. Whereas it is well known that DTT has the potential to prevent the formation of disulfide bonds, we cannot fully exclude the possibility, that DTT reduces pre-existing disulfide bonds in our assay.

Using the conditions defined in the pilot experiment mentioned above, we then analyzed the amount of protein carbonyls in extracts from young and senescent HDF. This experiment revealed a significant increase in the amount of carbonyls in several protein bands as shown by Oxyblot ${ }^{\mathrm{TM}}$ (Fig. 1b). Similarly, a significant increase in the production of protein carbonyls, involving several protein species, was observed in senescent human umbilical vein endothelical cells (HUVEC) (Fig. 1c). As in the case of fibroblasts, pre-incubation of young HUVEC with $\mathrm{H}_{2} \mathrm{O}_{2}$ resulted in the appearance of additional protein 


\begin{tabular}{|c|c|c|c|c|c|c|}
\cline { 2 - 7 } \multicolumn{1}{c|}{} & \multicolumn{3}{c|}{$y$} & s & \multicolumn{2}{c|}{ c } \\
\hline $\begin{array}{c}\text { H202 } \\
(750 \mu M, 1 h)\end{array}$ & - & - & + & - & - & - \\
\hline $\begin{array}{c}\text { DTr } \\
(50 m M)\end{array}$ & + & - & - & - & - & - \\
\hline $\begin{array}{c}\text { DNPI } \\
\text { derivatized }\end{array}$ & + & + & + & + & - & + \\
\hline
\end{tabular}
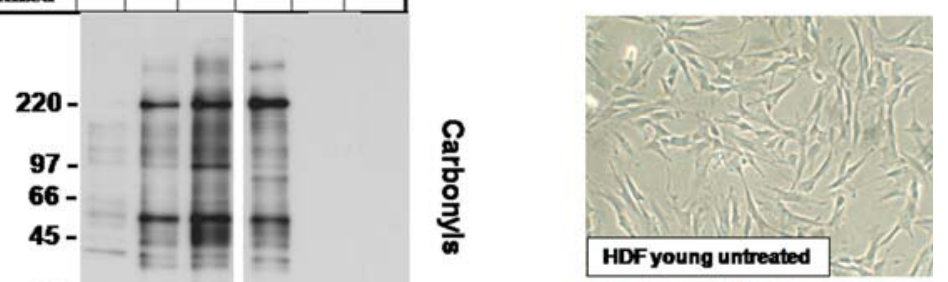

30 -
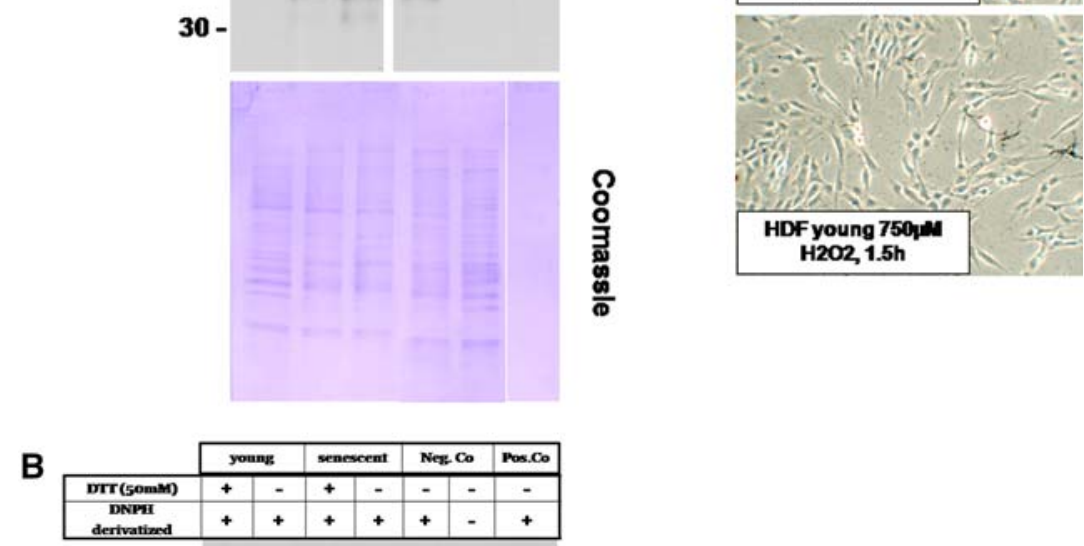

\begin{tabular}{c}
$\underset{\text { DNPII }}{\text { derivationed }}$ \\
\hline
\end{tabular}
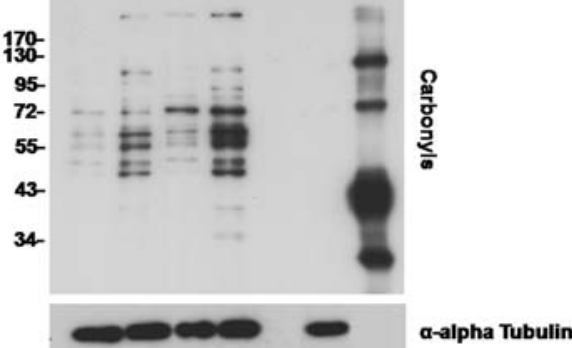

\begin{tabular}{|c|c|c|c|c|c|c|c|c|}
\hline & & & & & & & Sen. & $\infty$ \\
\hline $\begin{array}{c}\mathrm{HzO2} \\
(750 \mu \mathrm{M}, \text {, h) }\end{array}$ & - & + & - & - & - & + & - & - \\
\hline DTr (50mM) & - & - & - & - & + & + & + & - \\
\hline $\begin{array}{c}\text { DNPI } \\
\text { derivatized }\end{array}$ & + & + & + & - & + & + & + & - \\
\hline
\end{tabular}
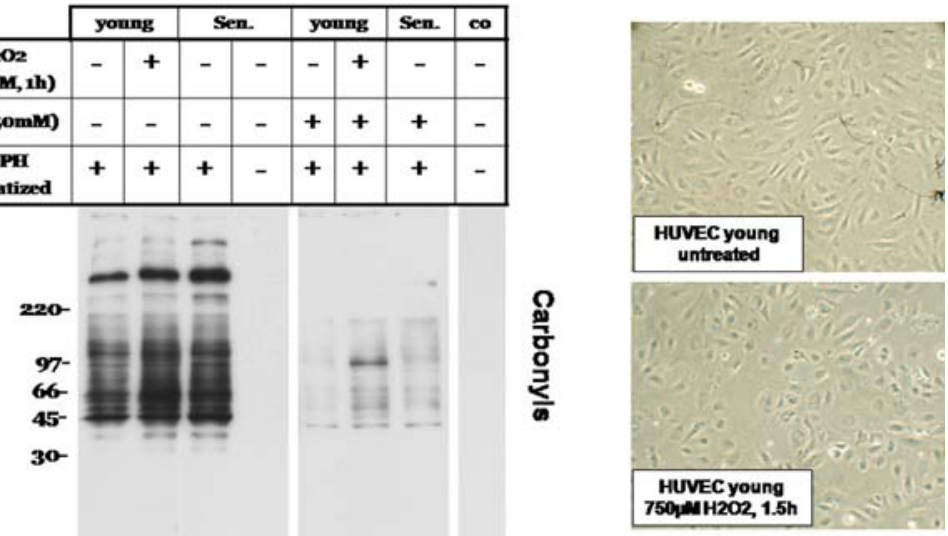

a-alpha Tubulin 
A

A

\section{HDF}

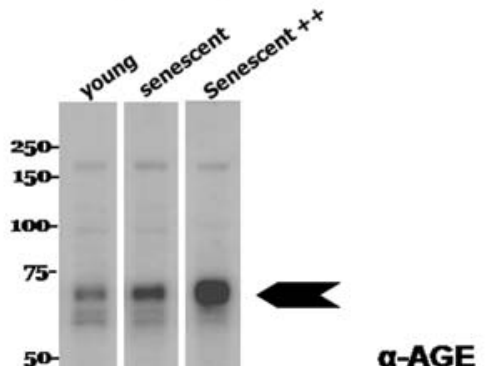

${ }^{37-}=-\infty$

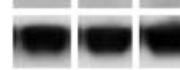

$\alpha-A G E$

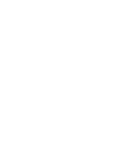

a-alpha Tubulin

\section{B HUVEC}

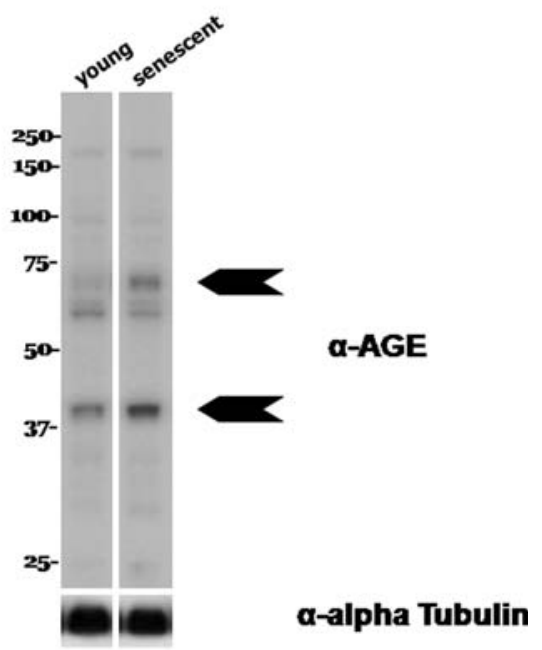

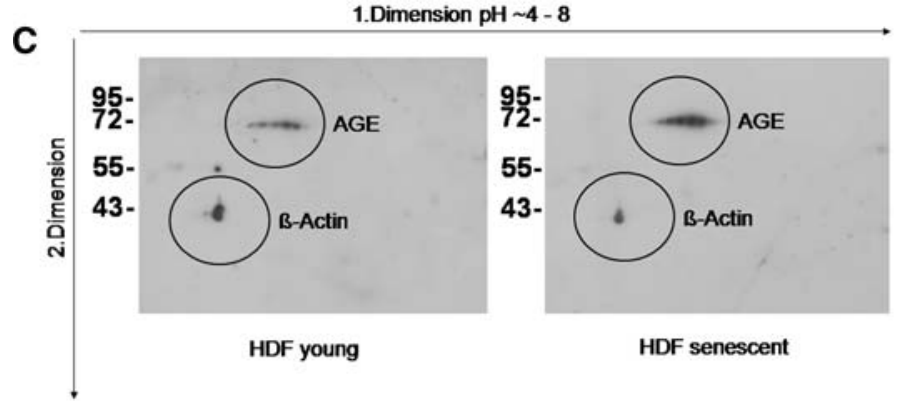

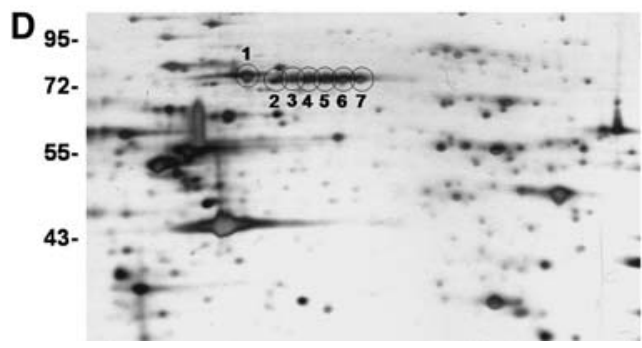

Fig. 2 AGE-modified proteins in senescent human cells. a Extracts from young and senescent human diploid fibroblasts were run on SDS-PAGE and analyzed by Western blot for the appearance of AGE-modified protein species. In addition, extracts from postmitotic cultures of senescent fibroblasts with extended culturing for two additional weeks (senescent ++ ) were also analysed. Western blot for alpha tubulin served as a loading control. The major species representing AGE-modified cellular proteins are indicated by arrows. b Young and senescent HUVEC were lysed and cellular extracts separated by SDS-PAGE. Using antibodies to AGE-modified proteins the abundance of AGE-modified proteins was analyzed. Alpha tubulin was used as a loading control. Arrows point to the two major species of age-modified proteins both of which are increased in senescent cell extracts. c Proteins were extracted from young and senescent human diploid fibroblasts and analyzed by $2 \mathrm{D}$ gel electrophoresis followed by Western blot using antibodies against AGE-modified proteins and $\beta$-actin, respectively. In each case the overlay of the AGE-blot and the $\beta$-actin blot are shown. d Extracts from senescent cells were run on $2 \mathrm{D}$ gels as in panel $\mathrm{C}$ and polyacrylamide gels were silver stained. Overlaying the AGE Western blot and the silver stained gels we identified seven prominent spots in the silver gel that co-localize with protein species that are positive for AGE modification. The seven spots indicated in this panel were excised and analyzed by mass spectrometry 
carbonyls (Fig. 1c), validating the experimental protocol. When the overall level of protein carbonyls was determined by densitometric analysis of three independent Western blots each, we found that the level of carbonylated proteins was increased 4.8 $( \pm 2.1)$ fold in senescent fibroblasts and $2.3( \pm 0.7)$ fold in senescent HUVEC. The data obtained suggest that in both cell types a few proteins are major targets for carbonyl formation. However, the identity of these proteins remains uncertain at this point.

Increased AGE modification of proteins in senescent cells

To analyze the modification of cellular proteins with advanced glycation end-products (AGE), extracts from HDF and HUVEC were analyzed by SDSPAGE followed by Western Blot with an antibody specifically recognizing AGE-modified proteins. This experiment revealed two prominent bands of AGEmodified proteins in senescent fibroblasts (Fig. 2a), and the intensity of these bands was even increased in cells, which were kept in culture for additional 2 weeks after the culture had reached senescence (Fig. 2a). The increase of protein modification could be due to either increased levels of oxidative stress, or to a reduced capacity to eliminate modified proteins via the proteasome, or a combination of both. Further studies will be required to address this point. Two protein bands of the same molecular weight were also detected by AGE Western Blot in senescent HUVEC (Fig. 2b), raising the possibility that similar proteins are targeted by AGE modification in both cell types; however, more work will be required to address this point.

Identification of Hsc70 as AGE target in senescent fibroblasts

For further characterization, extracts from senescent HDF were separated by 2D-Gel electrophoresis, blotted and probed with the antibody against AGEmodified proteins. Using this technique, the high molecular weight band (around $70 \mathrm{kDa}$; see Fig. 2a) was resolved into a series of discrete spots, differing in the isoelectric point (Fig. 2c). A silver gel was run in parallel (Fig. 2d) and the proteins present in seven discrete spots analyzed by mass spectrometry. This revealed that $\mathrm{Hsc} 70$ was the major protein species in spot 1 (Table 1). MS analysis of spots 2 through 7 revealed that those spots represent albumin. The results obtained so far suggest Hsc70 as potential intracellular target for AGE modification in senescent cells. Proteins of the large heat shock protein family have been described as target for oxidative modification in other systems (Hernebring et al. 2006). The relevance of AGE-modified albumin in senescent fibroblasts, as revealed here, is less clear and requires further investigation. Since lysine is the major amino acid targeted by AGE modification, the lysine content of a given protein will determine the potential of this protein to be modified by AGE. Whereas the HSC70 polypeptide identified by us has a rather normal lysine content $(6 \%)$, the lysine content of albumin amounts to roughly $25 \%$, which may explain in part the high degree of AGE modification observed for this protein.To confirm the identification of $\mathrm{Hsc70}$ as target for AGE modification, extracts from senescent fibroblasts were separated by SDS-PAGE and subjected to Western blot analysis by antibodies to AGE-modified proteins. Subsequently, the AGE Western blot was stripped and reprobed with anti Hsc70 antibodies (Fig. 3a). This experiment revealed that the broad band obtained with anti AGE antibodies apparently consists of two distinct protein species, one of which (i.e., the slower migrating band) is also recognized by the anti-Hsc 70 antibody. This experiment also revealed that the levels of $\mathrm{Hsc} 70$ are reduced in senescent cells, whereas the level of AGE-modified proteins is strongly increased. To confirm this finding, extracts from senescent HDF were immunoprecipitated with antibodies to $\mathrm{Hsc70}$ and the immune precipitates were separated by SDS-PAGE. Subsequently, the gel was blotted and probed with antibodies to AGE-modified proteins. Immunoprecipitation with $\mathrm{Hsc70}$ antibodies resulted in two bands, the lower of which was also detected with control antibodies. The identity of the precipitated protein as Hsc70 was also confirmed by Western blot to $\mathrm{Hsc} 70$ (Fig. 3b).

\section{Conclusion}

The data reported in this communication suggest that with replicative senescence there is a significant 
Table 1 MS identification of Hsc70 as AGE target

\begin{tabular}{|c|c|c|c|c|c|}
\hline Sequence & $\mathrm{MH}+$ & $\%$ by Mass & Position & $\%$ by AA's & Xcorr \\
\hline TTPSYVAFTDTER & $1,487.7$ & 2.1 & $37-49$ & 2.01 & 2.94 \\
\hline TTPSYVAFTDTERLIGDAAK & $2,156.09$ & 3.04 & $37-56$ & 3.1 & 3.48 \\
\hline LIGDAAKNQVAMNPTNTVFDAK & $2,318.18$ & 3.27 & $50-71$ & 3.41 & 4.14 \\
\hline NQVAMNPTNTVFDAK & $1,649.8$ & 2.33 & $57-71$ & 2.32 & 4.84 \\
\hline NQVAMNPTNTVFDAKR & $1,805.9$ & 2.55 & $57-72$ & 2.48 & 5.00 \\
\hline RFDDAVVQSDMK & $1,410.67$ & 1.99 & $77-88$ & 1.86 & 3.62 \\
\hline VQVEYKGETK & $1,180.62$ & 1.67 & $103-112$ & 1.55 & 2.93 \\
\hline SFYPEEVSSMVLTK & $1,616.79$ & 2.28 & $113-126$ & 2.17 & 3.51 \\
\hline MKEIAEAYLGK & $1,252.66$ & 1.77 & $127-137$ & 1.7 & 3.87 \\
\hline TVTNAVVTVPAYFNDSQR & 1,982 & 2.8 & $138-155$ & 2.79 & 4.01 \\
\hline QATKDAGTIAGLNVLR & $1,627.91$ & 2.3 & $156-171$ & 2.48 & 3.83 \\
\hline DAGTIAGLNVLR & $1,199.67$ & 1.69 & $160-171$ & 1.86 & 4.25 \\
\hline IINEPTAAAIAYGLDKK & $1,787.99$ & 2.52 & $172-188$ & 2.63 & 5.12 \\
\hline STAGDTHLGGEDFDNR & $1,691.73$ & 2.39 & $221-236$ & 2.48 & 4.15 \\
\hline MVNHFIAEFK & $1,235.62$ & 1.74 & $237-246$ & 1.55 & 3.15 \\
\hline MVNHFIAEFKR & $1,391.73$ & 1.96 & $237-247$ & 1.7 & 2.97 \\
\hline ARFEELNADLFR & $1,480.75$ & 2.09 & $300-311$ & 1.86 & 3.86 \\
\hline ARFEELNADLFRGTLDPVEK & $2,320.19$ & 3.27 & $300-319$ & 3.1 & 2.67 \\
\hline FEELNADLFR & $1,253.62$ & 1.77 & $302-311$ & 1.55 & 3.35 \\
\hline GTLDPVEKALR & $1,198.68$ & 1.69 & $312-322$ & 1.7 & 2.98 \\
\hline GTLDPVEKALRDAK & $1,512.84$ & 2.14 & $312-325$ & 2.17 & 2.40 \\
\hline DAKLDKSQIHDIVLVGGSTR & $2,152.17$ & 3.04 & $323-342$ & 3.1 & 4.83 \\
\hline LDKSQIHDIVLVGGSTR & $1,838.01$ & 2.59 & $326-342$ & 2.63 & 5.09 \\
\hline SQIHDIVLVGGSTR & $1,481.81$ & 2.09 & $329-342$ & 2.17 & 4.49 \\
\hline LLQDFFNGK & $1,081.57$ & 1.53 & $349-357$ & 1.39 & 2.03 \\
\hline LLQDFFNGKELNK & $1,565.83$ & 2.21 & $349-361$ & 2.01 & 3.74 \\
\hline SINPDEAVAYGAAVQAAILSGDK & $2,260.15$ & 3.19 & $362-384$ & 3.56 & 6.24 \\
\hline QTQTFTTYSDNQPGVLIQVYEGER & $2,774.33$ & 3.92 & $424-447$ & 3.72 & 4.44 \\
\hline AMTKDNNLLGK & $1,204.64$ & 1.7 & $448-458$ & 1.7 & 2.82 \\
\hline ITITNDKGR & $1,017.57$ & 1.44 & $501-509$ & 1.39 & 2.63 \\
\hline LSKEDIER & 989.53 & 1.4 & $510-517$ & 1.24 & 2.67 \\
\hline MVQEAEKYKAEDEKQR & $1,981.96$ & 2.8 & $518-533$ & 2.48 & 5.25 \\
\hline NSLESYAFNMK & $1,303.6$ & 1.84 & $540-550$ & 1.7 & 3.90 \\
\hline ELEKVCNPIITK & $1,386.77$ & 1.96 & $598-609$ & 1.86 & 2.46 \\
\hline VCNPIITK & 887.5 & 1.25 & $602-609$ & 1.24 & 2.04 \\
\hline
\end{tabular}

The table presents the observed amino acid sequences, the singly protonated molecular ions $\left(\mathrm{MH}^{+}\right)$of the Hsc70 fragments, the percentage of the mass ( $\%$ mass), the amino acid residues (AA), the percentage of the Hsc70 amino acid sequence of the specific fragments (\% AA) and the cross-correlation score (Xcorr) found for spot 1 of Fig. $2 \mathrm{~d}$

increase in the relative content of carbonylated proteins and AGE-modified proteins suggesting that oxidative damage to proteins contributes to senescence, as has been suggested by others before. The current study also suggests that specific protein species are selective targets for oxidative damage in both fibroblasts and endothelial cells. Whereas, most of the targets for oxidative stress remain to be identified, in the current study we have identified heat-shock cognate protein 70 as a bona fide target 

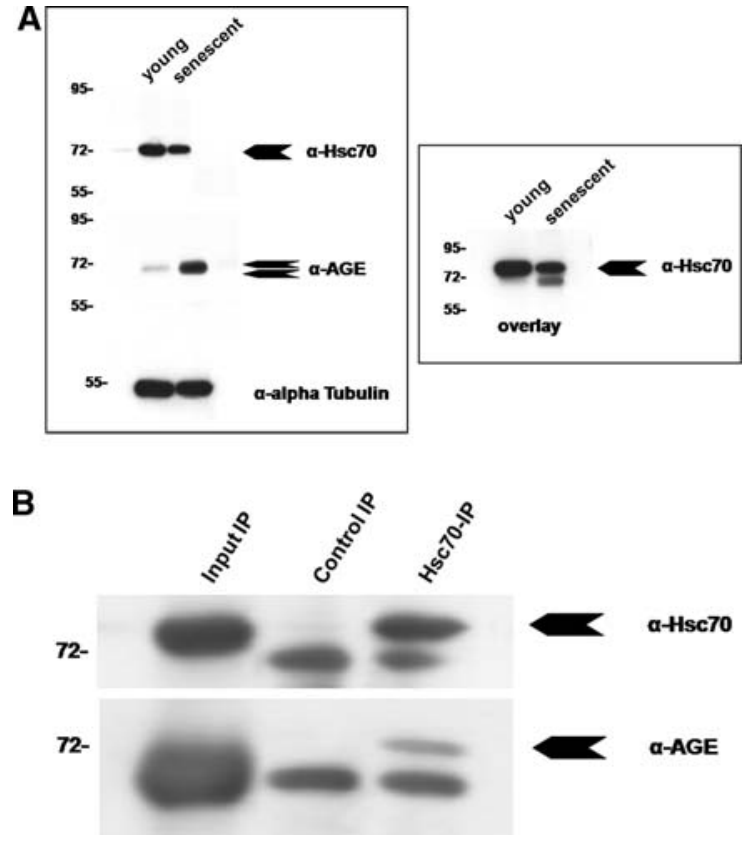

Fig. 3 Identification of HSC70 as bona fide AGE target. a Extracts from young and senescent human diploid fibroblasts were separated by SDS-PAGE and blotted with antibodies to Hsc70 (upper left panel). The blot was stripped and re-blotted with antibodies to AGE-modified human proteins (middle left panel); alpha tubulin was used as a loading control (lower left panel). In the right panel, overlay of the $\mathrm{Hsc} 70$ and AGE signals is shown. The position of the Hsc70 protein species is indicated by an arrow. Since the signals obtained with the AGE antibody were much stronger than the signals obtained with the HSC70 antibody, the composed picture was produced by overlaying a regular exposure of HSC70 blot with a weaker exposure of the AGE blot. As a result of this, the double band is revealed much better in the overlay than in the AGE blot alone. b Extracts from senescent human fibroblasts were immunoprecipitated with antibodies to $\mathrm{Hsc} 70$ or antibodies of the same isotype (control). An aliquot of the input is also shown. Immunoprecipitated proteins were run on an SDS gel and analyzed by Western blot using antibodies to Hsc70 and AGE-modified proteins, respectively. The arrow depicts the position of the Hsc70 species, which is recognized by both antibodies used in this study. The lower band most likely represents albumin, in line with its apparent molecular weight of $70 \mathrm{kDa}$ and the fact that albumin was identified as AGE target by MS (see Fig. 2)

for AGE-modification in senescent human fibroblasts. More work will be required to establish a causeeffect relationship between oxidative modifications and the buildup of the senescent phenotype.

Acknowledgments This work was supported by the Austrian Science Funds through NFN S93 and the European Union through the integrated project MiMage (LSHM-CT-2004512020). We are grateful to Dr. Taras Stasyk for the builtup of 2D technology and we acknowledge the expert technical assistance by Hans-Peter Viertler and Michael Neuhaus.

Open Access This article is distributed under the terms of the Creative Commons Attribution Noncommercial License which permits any noncommercial use, distribution, and reproduction in any medium, provided the original author(s) and source are credited.

\section{References}

Ahmed EK, Picot CR, Bulteau AL, Friguet B (2007) Protein oxidative modifications and replicative senescence of WI38 human embryonic fibroblasts. Ann N Y Acad Sci 1119:88-96. doi:10.1196/annals.1404.020

Braig M, Schmitt CA (2006) Oncogene-induced senescence: putting the brakes on tumor development. Cancer Res 66:2881-2884. doi:10.1158/0008-5472.CAN-05-4006

Bulteau AL, Petropoulos I, Friguet B (2000) Age-related alterations of proteasome structure and function in aging epidermis. Exp Gerontol 35:767-777. doi:10.1016/S05315565(00)00136-4

Chen X, Liang H, Van Remmen H, Vijg J, Richardson A (2004) Catalase transgenic mice: characterization and sensitivity to oxidative stress. Arch Biochem Biophys 422:197-210. doi:10.1016/j.abb.2003.12.023

Dimri GP, Lee X, Basile G, Acosta M, Scott G, Roskelley C, Medrano EE, Linskens M, Rubelj I, Pereira-Smith O, Smith J (1995) A biomarker that identifies senescent human cells in culture and in aging skin in vivo. Proc Natl Acad Sci USA 92:9363-9367. doi:10.1073/pnas.92.20.9363

Goldstein S, Korczack LB (1981) Status of mitochondria in living human fibroblasts during growth and senescence in vitro: use of the laser dye rhodamine 123. J Cell Biol 91:392-398. doi:10.1083/jcb.91.2.392

Grune T, Shringarpure R, Sitte N, Davies K (2001) Age-related changes in protein oxidation and proteolysis in mammalian cells. J Gerontol A Biol Sci Med Sci 56:B459-B467

Harman D (1956) Aging: a theory based on free radical and radiation chemistry. J Gerontol 11:298-300

Hayflick L (1997) Mortality and immortality at the cellular level. A review. Biochemistry (Mosc) 62:1180-1190

Hernebring M, Brolen G, Aguilaniu H, Semb H, Nystrom T (2006) Elimination of damaged proteins during differentiation of embryonic stem cells. Proc Natl Acad Sci USA 103:7700-7705. doi:10.1073/pnas.0510944103

Huang TT, Carlson EJ, Gillespie AM, Shi Y, Epstein CJ (2000) Ubiquitous overexpression of $\mathrm{CuZn}$ superoxide dismutase does not extend life span in mice. J Gerontol A Biol Sci Med Sci 55:B5-B9

Jaffe EA, Nachman RL, Becker CG, Minick CR (1973) Culture of human endothelial cells derived from umbilical veins. Identification by morphologic and immunologic criteria. J Clin Invest 52:2745-2756. doi:10.1172/JCI107470

Kokoszka JE, Coskun P, Esposito LA, Wallace DC (2001) Increased mitochondrial oxidative stress in the Sod2 (+/-) mouse results in the age-related decline of mitochondrial function culminating in increased apoptosis. Proc Natl 
Acad Sci USA 98:2278-2283. doi:10.1073/pnas.05162 7098

Levine RL, Stadtman ER (2001) Oxidative modification of proteins during aging. Exp Gerontol 36:1495-1502. doi: 10.1016/S0531-5565(01)00135-8

Martinez AO, Vara C, Castro J (1987) Increased uptake and retention of rhodamine 123 by mitochondria of old human fibroblasts. Mech Ageing Dev 39:1-9. doi:10.1016/00476374(87)90081-9

Minamino T, Miyauchi H, Yoshida T, Ishida Y, Yoshida H, Komuro I (2002) Endothelial cell senescence in human atherosclerosis: role of telomere in endothelial dysfunction. Circulation 105:1541-1544. doi:10.1161/01.CIR.000 0013836.85741 .17

Orr WC, Sohal RS (1994) Extension of life-span by overexpression of superoxide dismutase and catalase in Drosophila melanogaster. Science 263:1128-1130. doi: 10.1126/science. 8108730

Petropoulos I, Friguet B (2005) Protein maintenance in aging and replicative senescence: a role for the peptide methionine sulfoxide reductases. Biochim Biophys Acta 1703:261-266

Petropoulos I, Conconi M, Wang X, Hoenel B, Bregegere F, Milner Y, Friguet B (2000) Increase of oxidatively modified protein is associated with a decrease of proteasome activity and content in aging epidermal cells. J Gerontol A Biol Sci Med Sci 55:B220-B227

Ramirez RD, Morales CP, Herbert BS, Rohde JM, Passons C, Shay JW, Wright WE (2001) Putative telomere-independent mechanisms of replicative aging reflect inadequate growth conditions. Genes Dev 15:398-403. doi: $10.1101 / \operatorname{gad} .859201$

Reddy VP, Beyaz A (2006) Inhibitors of the Maillard reaction and AGE breakers as therapeutics for multiple diseases. Drug Discov Today 11:646-654. doi:10.1016/j.drudis. 2006.05.016

Ressler S, Bartkova J, Niederegger H, Bartek J, ScharffetterKochanek K, Jansen-Durr P, Wlaschek M (2006) p16INK4A is a robust in vivo biomarker of cellular aging in human skin. Aging Cell 5:379-389. doi:10.1111/ j.1474-9726.2006.00231.x

Schriner SE, Linford NJ, Martin GM, Treuting P, Ogburn CE, Emond M, Coskun PE, Ladiges W, Wolf N, Van Remmen H, Wallace DC, Rabinovitch PS (2005) Extension of murine lifespan by overexpression of catalase targeted to mitochondria. Science 308:1909-1911

Serrano M, Blasco MA (2001) Putting the stress on senescence. Curr Opin Cell Biol 13:748-753. doi:10.1016/S0955-0674 (00)00278-7
Shay JW, Wright WE (2001) Ageing and cancer: the telomere and telomerase connection. Novartis Found Symp 235:116-125. doi:10.1002/0470868694.ch11

Sohal RS, Mockett RJ, Orr WC (2002) Mechanisms of aging: an appraisal of the oxidative stress hypothesis. Free Radic Biol Med 33:575-586. doi:10.1016/S0891-5849(02)00886-9

Stadtman ER, Levine RL (2000) Protein oxidation. Ann N Y Acad Sci 899:191-208

Toussaint O, Royer V, Salmon M, Remacle J (2002) Stressinduced premature senescence and tissue ageing. Biochem Pharmacol 64:1007-1009. doi:10.1016/S0006-2952(02) 01170-X

Ungvari ZI, Labinskyy N, Gupte SA, Chander PN, Edwards JG, Csiszar A (2008) Dysregulation of mitochondrial biogenesis in vascular endothelial and smooth muscle cells of aged rats. Am J Physiol Heart Circ Physiol 294:H2121-H2128

Unterluggauer H, Hampel B, Zwerschke W, Jansen-Durr P (2003) Senescence-associated cell death of human endothelial cells: the role of oxidative stress. Exp Gerontol 38:1149-1160. doi:10.1016/j.exger.2003.08.007

Unterluggauer H, Hutter E, Voglauer R, Grillari J, Voth M, Bereiter-Hahn J, Jansen-Durr P, Jendrach M (2007) Identification of cultivation-independent markers of human endothelial cell senescence in vitro. Biogerontology 8:383-397. doi:10.1007/s10522-007-9082-x

Vasile E, Tomita Y, Brown LF, Kocher O, Dvorak HF (2001) Differential expression of thymosin beta-10 by early passage and senescent vascular endothelium is modulated by VPF/VEGF: evidence for senescent endothelial cells in vivo at sites of atherosclerosis. FASEB J 15:458-466. doi: 10.1096/fj.00-0051com

Wagner M, Hampel B, Bernhard D, Hala M, Zwerschke W, Jansen-Durr P (2001) Replicative senescence of human endothelial cells in vitro involves G1 arrest, polyploidization and senescence-associated apoptosis. Exp Gerontol 36:1327-1347. doi:10.1016/S0531-5565(01)00105-X

Wessel D, Flugge UI (1984) A method for the quantitative recovery of protein in dilute solution in the presence of detergents and lipids. Anal Biochem 138:141-143. doi: 10.1016/0003-2697(84)90782-6

Widmer R, Ziaja I, Grune T (2006) Protein oxidation and degradation during aging: role in skin aging and neurodegeneration. Free Radic Res 40:1259-1268. doi:10.1080/ 10715760600911154

von Zglinicki T, Saretzki G, Docke W, Lotze C (1995) Mild hyperoxia shortens telomeres and inhibits proliferation of fibroblasts: a model for senescence? Exp Cell Res 220:186-193. doi:10.1006/excr.1995.1305 